5. Лавринович О.В. Реформа органів виконавчої влади: перезавантаження. Урядовий кур’єp. 2011. № 35. С. 8.

6. Лазарев Б.М. Государственная служба. Москва : Академический правовой университет при Институте государства и права РАН, 1993. 16 с.

7. Іллічов М.О. Адміністративно-правове становище посадової особи органів внутрішніх справ України : дис. ... канд. юрид. наук : 12.00.07. Київ, 2002. 173 с.

8. Державне управління та державна служба: словник-довідник/за ред. О.Ю. Оболенського. Київ : КНЕУ, 2005. 480 с.

9. Тихомиров Ю.А. Публичное право : учебник. Москва : БЕК, 1995. 496 с. 1990. $482 \mathrm{c}$.

11. Адміністративне право України. Повний курс : підручник / Галунько В., Діхтієвський П., Кузьменко О., Стеценко С. та ін. Херсон : ОЛДІ-ПЛЮС, 2018. 446 с.

12. Теремецький В.І. Особливості адміністративно-правового статусу державної податкової служби України. Право і безпека. 2012. № 2(44). С. 82-88.

13. Теремецький B.I. Податкові правовідносини в Україні : монографія. Харків : Диса плюс, 2012. 648 с.

14. Державне будівництво і місцеве самоврядування в Україні : підручник /за ред. С.Г. Серьогіної. Харків : Право, 2005. 256 с.

УДК 342.9.08:35.083

DOI https://doi.org/10.32844/2618-1258.2019.6.28

ЗАБОЛОТНИЙ А.В.

\title{
ОСОБЛИВОСТІ ВПЛИВУ АДМІНІСТРАТИВНО-ПРАВОВИХ ЗАСАД ПРОФЕСІЙНОЇ ДІЯЛЬНОСТІ ДЕРЖАВНИХ СЛУЖБОВЦІВ НА СЛУЖБУ В ОРГАНАХ МІСЦЕВОГО САМОВРЯДУВАННЯ
}

\begin{abstract}
Аргументовано, що особлива природа і завдання місцевого самоврядування визначили потребу у формуванні власної професійної служби і відповідного законодавчого закріплення адміністративно-правових засад проходження такої служби. Зроблено висновок, що служба в органах місцевого самоврядування та державна служба є окремими підвидами публічної служби, проте окремі процедурні питання, пов'язані з проходженням служби в органах місцевого самоврядування, регулюються нормами адміністративного законодавства, що упорядковує проходження державної служби. Визначено, що служба в органах місцевого самоврядування та державна служба є окремими підвидами публічної служби, проте окремі процедурні питання, пов'язані з проходженням служби в органах місцевого самоврядування, регулюються нормами адміністративного законодавства, що упорядковує проходження державної служби. У зв'язку з цим важливого значення набуває оновлення існуючої моделі проходження служби в органах місцевого самоврядування, яка буде спроможна реалізувати структурні реформи та забезпечить сталий розвиток територіальних громад для задоволення потреб суспільства, а також сприятиме функціонуванню органів місцевого самоврядування для забезпечення створення та надання населенню високоякісних і доступних адміністративних, соціальних та інших послуг. Зроблено висновок, що сьогодні надзвичайно актуальними є питання організації підготовки, перепідготовки та підвищення кваліфікації кадрів для служби в органах місцевого самоврядування: вивчення потреби у навчанні, формування та розподіл державного замовлення на підготовку кадрів, формування мережі навчальних закладів, координації ліцензування та акредитація освітньої діяльно-
\end{abstract}

( ) ЗАБОЛОТНИЙ А.В. - здобувач (Науково-дослідний інститут публічного права) 
сті, розробки освітньо-професійних програм та відповідних інструктивно-методичних матеріалів. Зважаючи на це, нагальним питанням сьогодення є прийняття нової редакції Закону України «Про службу в органах місцевого самоврядування», в якому мають бути враховані міжнародні рекомендації щодо наближення служби в органах місцевого самоврядування до європейських принципів, які висуваються до країн-кандидатів на вступ до $\mathrm{CC}$, а також принципів «належного врядування», які закріплені рішеннями Ради Європи.

Ключові слова: місиеве самоврядування, державна служба, проходження служби, норми адміністративного права, законодавство.

It is argued that the special nature and tasks of local self-government have identified the need for the formation of their own professional service and appropriate legislative consolidation of the administrative and legal bases of such service. It has been concluded that local government service and civil service are separate subspecies of public service, but some procedural issues related to local government service are governed by the rules of administrative law governing public service. It has been determined that local government service and civil service are separate subspecies of public service, but some procedural issues related to local government service are governed by the rules of administrative law governing public service. In this context, it is important to update the existing model of local self-government service delivery, which will be able to implement structural reforms and ensure the sustainable development of territorial communities to meet the needs of the community, as well as to promote the functioning of local self-government bodies to ensure the creation and provision of high quality population and available administrative, social, and other services. It is concluded that the issues of organization of training, retraining and advanced training of personnel for service in local self-government bodies are extremely relevant today: study of the need for training, formation and distribution of the state order for training, formation of a network of educational institutions, coordination of licensing and accreditation of educational activities, development of educational and professional programs and related instructional materials. In view of this, the urgent issue today is the adoption of a new version of the Law of Ukraine "On Service in Local Self-Government Bodies", which should take into account international recommendations on approximation of the service in local self-government bodies to the European principles that apply to the candidate countries for accession to the EU , as well as the principles of "good governance", which are enshrined in Council of Europe decisions.

Key words: local self-government, public service, service, administrative law, legislation.

Вступ. В умовах активного продовження децентралізаційних процесів в Україні та реформи системи органів місцевого самоврядування, у тому числі оновлення підходів до організації їх діяльності, надзвичайно важливого значення набуває дослідження інституту служби в органах місцевого самоврядування, з'ясування специфіки професійної діяльності державних службовців в органах місцевого самоврядування, окреслення особливостей правового регулювання професійної діяльності цієї категорії державних службовців та визначення особливостей впливу норм адміністративного права на ці процеси.

Насамперед варто зазначити, що правове регулювання служби в органах місцевого самоврядування здійснюється Конституцією України, законами України «Про місцеве самоврядування в Україні», «Про статус депутатів місцевих рад», «Про місцеві вибори», «Про службу в органах місцевого самоврядування в Україні» та іншими законами України. Положення вказаних нормативно-правових актів визначають ключові засади функціонування органів місцевого самоврядування, регулюють механізм проходження служби в органах місцевого самоврядування, а отже, є адміністративно-правовими. Підтвердженням обгрунтованості вказаної точки зору є позиція О.І. Безпалової, яка зазначає, що правові відносини, які виникають під час виконання органами місцевого самоврядування покладених на них обов'язків, здійснюються в рамках управлінської діяльності, яка своєю чергою повинна регулюватися нормами адміністративного права $[1 ; 2]$. 
Стан дослідження. Як показав аналіз стану наукової розробки проблем місцевого самоврядування загалом та муніципальної служби зокрема, українськими вченими створено підгрунтя для ії̈ подальшого вивчення. Вагомий внесок у дослідження цієї проблематики зробили М. Баймуратов, О. Батанов, Н. Гончарук, В. Кравченко, В. Куйбіда, Т. Мотренко, Н. Нижник, Н. Плахотнюк, М. Пухтинський, С. Серьогін та інші. Водночас у наукових публікаціях питання, пов'язані зі становленням інституту муніципальної служби, сучасним станом реалізації положень адміністративного законодавства, що регулює службу в органах місцевого самоврядування, досліджені не достатньою мірою. Протягом останніх років серед науковців триває дискусія щодо правомірності введення муніципальної служби в Україні як публічно-владної діяльності службовців органів місцевого самоврядування. Одні вчені вважають, що муніципальна служба є різновидом державної служби і не має особливих відмінностей від державної цивільної служби. Інші вчені вважають, що служба в органах місцевого самоврядування це самостійний інститут муніципальної влади, який має право на самостійне існування [3, с. 2].

Постановка завдання. Метою статті є дослідження особливостей впливу адміністративно-правових засад професійної діяльності державних службовців на службу в органах місцевого самоврядування.

Результати дослідження. Можна погодитися із думкою В.В. Кравченка про те, що служба в органах місцевого самоврядування має багато спільних рис з державною службою. Обидві ці служби базуються на спільних принципах публічної служби, зокрема, верховенства права, демократизму і законності, гуманізму, гласності, рівному доступі громадян до служби, професіоналізмі, компетентності, пріоритеті прав і свобод людини і громадянина, правової і соціальної захищеності службовця, позапартійності [4, с. 230]. При цьому не можна підтримати погляд автора у питанні самостійності кадрової політики в системі місцевого самоврядування.

Така самостійність, на нашу думку, можлива лише щодо виборних посад. Адміністративні посади мають повністю тотожний правовий статус з посадами державної служби, здійснюють професійну діяльність, керуючись Конституцією і законами України. Таким чином, правила прийому на роботу, проходження служби та звільнення мають регулюватися однаково. В іншому разі чинитиметься вплив місцевих політиків на кадрові призначення та розстановка «зручних» підлеглих на посади, що не сприятиме сталій роботі апаратів (виконавчих комітетів) місцевих рад, загрожуватиме втратою інституційної пам'яті, погіршенням якості документів, «здорового клімату» у колективі.

Конституція України розмежовує державну службу і службу в органах місцевого самоврядування як відносно самостійні форми публічної служби. Відповідно, службу в органах місцевого самоврядування не можна розглядати як частину державної служби, а службовців органів місцевого самоврядування - як державних службовців, що працюють в органах місцевого самоврядування. Це випливає з тих положень Конституції України, в яких місцеве самоврядування закріплюється як особлива форма публічної влади [1, с. 51].

Аналіз законотворчої практики під час прийняття нової редакції Закону України «Про державну службу» підтверджує згадане обгрунтування, адже серед поправок народних депутатів України була поправка народного депутата України А.С. Матвієнка щодо зміни назви законопроекту на: «Закон України «Про публічну службу». Згадана поправка відхилена профільним комітетом парламенту, незважаючи на те, що в низці європейських країн така назва вживається досить часто.

Засади правового врегулювання службових відносин в органах місцевого самоврядування закладені в Конституції України, відповідно до ст. 5 якої здійснення територіальною громадою питань місцевого значення може відбуватися як безпосередньо (через місцеві референдуми, загальні збори громадян, громадські слухання), так і через органи місцевого самоврядування, які для забезпечення своєї діяльності потребують спеціально підготовленого службового апарату. У ст. 38 Конституції України для громадян України закріплене рівне «право доступу до державної служби, а також до служби в органах місцевого самоврядування». Завданням служби в органах місцевого самоврядування є реалізація як власних повноважень місцевого самоврядування, так делегованих державою повноважень.

Особлива природа і завдання місцевого самоврядування визначили потребу у формуванні власної професійної служби і відповідного законодавчого закріплення адміністративно-правових засад проходження такої служби. Після прийняття Закону України «Про місцеве самоврядування в Україні» (1997 р.) дія чинного на той час Закону України «Про державну службу» (1993р.) була поширена на посадових осіб органів місцевого самоврядування. Така позиція законодавця, на думку Н.В. Янюк, не відображала специфіки і автономності служби в органах місцевого са- 
моврядування як окремого виду публічної служби, тому з часом виникла цілком обгрунтована необхідність у прийнятті відповідного закону [5].

Погоджуючись 3 позицією автора щодо автономності, варто зазначити, що про автономність може йтися лише стосовно неприпустимості впливу на прийняття рішень радою щодо розпорядження земельними ділянками, комунальною власністю тощо, а не стосовно питання кадрового забезпечення (прийом, кар'єра, звільнення), які мають регулюватися лише законом за ознакою професіоналізації служби.

Чинний Закон України «Про службу в органах місцевого самоврядування» прийнято Верховною Радою України 07 червня 2001 року (далі - Закон 2493). Цей закон регулює правові, організаційні, матеріальні та соціальні умови реалізації громадянами України права на службу в органах місцевого самоврядування, визначає загальні засади діяльності посадових осіб місцевого самоврядування, їх адміністративно-правовий статус, порядок та правові гарантії перебування на службі в органах місцевого самоврядування.

Згідно з Законом 2493 служба в органах місцевого самоврядування - це професійна, на постійній основі діяльність громадян України, що займають посади в органах місцевого самоврядування та їх апаратів, яка спрямована на забезпечення завдань і функцій місцевого самоврядування, реалізацію повноважень цих органів.

Посада в органах місцевого самоврядування - це передбачена законодавством України, статутом від повідної територіальної громади та визначена структурою і штатним розписом первинна структурна одиниця органів місцевого самоврядування та їх апарату з установленими повноваженнями щодо виконання завдань і функцій місцевого самоврядування та відповідальністю за здійснення цих повноважень.

Унормовано також особливості посад, які на відміну від посад державних службовців поділяються на: виборні посади, на які особи обираються територіальної громадою; виборні посади, на які особи обираються або затверджуються відповідною радою; посади, призначення на які здійснюється відповідним головою на конкурсній основі чи за іншою процедурою, передбаченою законодавством України [1, с. 51].

Дія Закону 2493 не знімає низки неузгодженостей, прогалин та колізій порівняно із новим законодавством про державну службу, тож на часі $є$ підготовка нового закону про службу в органах місцевого самоврядування.

Одним із найскладніших питань $є$ організація підготовки, перепідготовки та підвищення кваліфікації кадрів для служби в органах місцевого самоврядування: вивчення потреби у навчанні, формування та розподіл державного замовлення на підготовку кадрів, формування мережі навчальних закладів, координація ліцензування та акредитація освітньої діяльності, розробка освітньо-професійних програм та відповідних інструктивно-методичних матеріалів.

Проект Закону України «Про службу в органах місцевого самоврядування» (від 02.09.2019 № 1223) (нова редакція) розроблено НАДС відповідно до пункту 6.3 показників результативності Контракту для України з розбудови держави, яким передбачено прийняття Верховною Радою України, набрання чинності та ефективне впровадження Закону «Про службу в органах місцевого самоврядування», розробленого на основі європейських принципів державного управління та кращого європейського досвіду та відповідно до Закону України «Про державну службу».

Ратифікувавши Угоду про асоціацію між Україною та Європейським Союзом, Європейським співтовариством 3 атомної енергії і їхніми державами-членами, Україна взяла на себе зобов'язання наближення служби в органах місцевого самоврядування до європейських принципів, які висуваються до країн-кандидатів на вступ до СС, а також принципів «належного врядування», які закріплені рішеннями Ради Європи.

Доцільність вказаного зумовлена тим, що система служби, яка має якісно розроблене правове підгрунтя та належне управління, дозволяє суспільству, державі і громадянам досягати високого рівня професіоналізму, сталості та якості служби на усіх рівнях системи органів місцевого самоврядування та надавати кращі послуги громадянам і бізнесу.

Запровадження нових принципів та механізмів служби в органах місцевого самоврядування на основі європейських принципів публічної служби стало одним із завдань Уряду відповідно до розділу VII «Децентралізація та реформа публічної адміністрації» Програми діяльності Кабінету Міністрів України, схваленої Постановою Верховної Ради України від 29 вересня 2019 року № 849.

Це завдання залишається актуальним для Уряду та передбачене Розділом II «Ефективне урядування» Плану пріоритетних дій Уряду, затвердженому розпорядженням Кабінету Міністрів 
України від 28 березня 2018 року № 244. Супроводження у Верховній Раді України проекту Закону України «Про службу в органах місцевого самоврядування» (від 02.09.2019 № 1223) (нова редакція), а також розроблення та подання Кабінетові Міністрів України проектів нормативно-правових актів, необхідних для реалізації Закону України «Про службу в органах місцевого самоврядування» після його прийняття є кроками, які мають бути виконані впродовж року.

Як зазначає Н.В. Янюк, правове регулювання служби в органах місцевого самоврядування в Україні має три рівні: положення Конституції України; закони, підзаконні нормативно-правові акти. Формування цього виду служби включає низку заходів, серед яких:

- встановлення посад та визначення посадових повноважень;

- визначення способів та порядку заміщення посад;

- визначення правил проходження служби;

- встановлення підстав та порядку звільнення зі служби;

- визначення правового статусу службовців [5].

Закон України «Про службу в органах місцевого самоврядування» залишається базовим для цього виду служби. Однак аналіз його положень свідчить, що він поширюється лише на діяльність посадових осіб органів місцевого самоврядування, їх правовий статус та правові гарантії перебування на службі. Згідно зі ст. 2 Закону визначальною ознакою для посадової особи місцевого самоврядування є здійснення організаційно-розпорядчих та консультативно-дорадчих функцій і отримання заробітної плати за рахунок місцевого бюджету, що звужує коло службовців. Аналогічний підхід у визначенні посадової особи містить Закон України «Про державну службу» 1993 року. За таким підходом статус багатьох службовців органів місцевого самоврядування залишився поза увагою законодавця. Це в певному сенсі обмежує розуміння служби в органах місцевого самоврядування, що закріплене у ст. 1 цього ж Закону. У проекті закону (реєстр. № 2489) цей недолік усунули. У ньому передбачено також регулювання діяльності службовців місцевого самоврядування (п. 7 ст. 1).

Недоліком чинного Закону «Про службу в органах місцевого самоврядування» $є$ наявність положень щодо приватно-публічного регулювання служби. У ст. 7 наголошено на тому, що правовий статус посадових осіб місцевого самоврядування визначається Конституцією України, законами України «Про місцеве самоврядування в Україні», «Про статус депутатів місцевих рад», «Про вибори депутатів місцевих рад та сільських, селищних, міських голів» (втратив чинність), цим та іншими законами України. Разом із тим у частині третій цієї статті зазначено, що на посадових осіб місцевого самоврядування поширюється дія законодавства України про працю 3 урахуванням особливостей, передбачених названим Законом. У ст. 20 цього Закону серед підстав припинення служби безпосередньо наголошено на пріоритеті норм трудового права: «Крім загальних підстав, передбачених Кодексом законів про працю України, служба в органах місцевого самоврядування припиняється на підставі і в порядку, визначених Законом України «Про місцеве самоврядування в Україні», цим та іншими законами України». Розпорошеність норм у різних законодавчих актах не завжди дає змогу забезпечити належний порядок їх застосування.

Слід також врахувати, що служба в органах місцевого самоврядування $\epsilon$ різновидом публічної служби, завданням якої є забезпечення публічного інтересу, а тому пріоритет має належати нормам публічного права. Проект Закону «Про службу в органах місцевого самоврядування» враховує цей момент. Проектом закону передбачено регулювання низки важливих питань: умови вступу на посаду, умови і порядок проведення конкурсу на заміщення посади, вимоги щодо актів про призначення на посаду, порядок присвоєння рангів, питання оцінювання результатів службової діяльності; порядку перепідготовки й підвищення кваліфікації службовців органів місцевого самоврядування, умови оплати праці і визначення посадових окладів [5, с. 98-99].

Варто зазначити, що проект Закону «Про службу в органах місцевого самоврядування» $\epsilon$ черговим важливим кроком у децентралізації влади і реформі місцевого самоврядування. Він впроваджує низку важливих положень Європейської хартії місцевого самоврядування, що ратифікована Парламентом 15 липня 1997 року. Зазначимо також, що Кабінет Міністрів України, НАДС та всеукраїнські асоціації органів місцевого самоврядування вважали за доцільне підписання законопроекту Президентом України, адже зазначене могло сприяти підтримці курсу держави на успішне реформування служби в органах місцевого самоврядування відповідно до взятих Україною міжнародних зобов'язань.

Порівняно із Законом України «Про службу в органах місцевого самоврядування» № 2493 до основних здобутків проекту Закону «Про службу в органах місцевого самоврядування» можна віднести: 
1) правову та організаційну самостійність служби, врегулювання статусу службовців органів місцевого самоврядування;

2) винятково конкурсний відбір на посади службовців місцевого самоврядування на основі професійної компетентності;

3) прозорість прийняття на службу в органи місцевого самоврядування;

4) розмежування виборних та адміністративних посад на місцевому рівні;

5) запровадження нової моделі оплати праці, що мінімізує суб'єктивізм керівника;

6) підвищення рівня мотивації службовця місцевого самоврядування (побудова кар'єри, конкурентний рівень заробітної плати);

7) самостійність органів місцевого самоврядування під час визначенні умов оплати праці;

8) впровадження ефективного механізму запобігання корупції;

9) професійне навчання службовців місцевого самоврядування;

10) створення умов прозорої діяльності органів місцевого самоврядування;

Окрім вищезазначеного, проект Закону «Про службу в органах місцевого самоврядування» вирішує проблеми:

1) забезпечення рівного доступу до служби в органах місцевого самоврядування на основі знань та особистих якостей;

2) недостатньої професійності інституту служби в органах місцевого самоврядування;

3) розмежування законодавства про службу в органах місцевого самоврядування та законодавства про працю;

4) невизначеності критеріїв віднесення посад в органах місцевого самоврядування до відповідних категорій (виключає ручний механізм віднесення посад);

5) непрозорої моделі оплати праці (усунення суб'єктивних підходів до визначення складників розміру заробітної плати та зв'язок між результатом роботи і рівнем оплати за неї);

6) підвищення ефективності, відкритості та гнучкості структури публічної адміністрації, здатної реалізовувати комплексні завдання місцевого самоврядування.

Водночас важливо не лише прийняття нового Закону України «Про службу в органах місцевого самоврядування», а й ефективне впровадження Закону (вироблення дієвого адміністративно-правового механізму реалізації його положень), що $є$ одним із показників виконання взятих Україною зобов'язань та передбачено стратегічними документами держави (Програма реформ Президента України «Стратегія сталого розвитку «Україна - 2020», Програма діяльності Кабінету Міністрів України та інші). У зв'язку з цим Законом передбачена розробка п'яти нормативно-правових актів і приведення інших актів законодавства у відповідність до його положень. Передбачається, що зазначене буде реалізовано Кабінетом Міністрів України у встановлений строк після прийняття доопрацьованого законопроекту Верховною Радою України, підписання редакції Закону Президентом України та набрання ним чинності.

Таким чином, можна дійти висновку, що служба в органах місцевого самоврядування та державна служба $є$ окремими підвидами публічної служби, проте окремі процедурні питання, пов'язані з проходженням служби в органах місцевого самоврядування, регулюються нормами адміністративного законодавства, що упорядковує проходження державної служби. У зв'язку 3 цим важливого значення набуває оновлення наявної моделі проходження служби в органах місцевого самоврядування, яка буде спроможна реалізувати структурні реформи та забезпечить сталий розвиток територіальних громад для задоволення потреб суспільства, а також сприятиме функціонуванню органів місцевого самоврядування для забезпечення створення та надання населенню високоякісних і доступних адміністративних, соціальних та інших послуг.

Висновки. Отже, сьогодні надзвичайно актуальними $є$ питання організації підготовки, перепідготовки та підвищення кваліфікації кадрів для служби в органах місцевого самоврядування, зокрема, вивчення потреби у навчанні, формування та розподіл державного замовлення на підготовку кадрів, формування мережі навчальних закладів, координації ліцензування та акредитація освітньої діяльності, розробки освітньо-професійних програм та відповідних інструктивно-методичних матеріалів. Зважаючи на це, нагальним питанням сьогодення $є$ прийняття нової редакції Закону України «Про службу в органах місцевого самоврядування», в якому мають бути враховані міжнародні рекомендації щодо наближення служби в органах місцевого самоврядування до європейських принципів, які висуваються до країн-кандидатів на вступ до ЄС, а також принципів «належного врядування», які закріплені рішеннями Ради Європи. 


\section{Список використаних джерел:}

1. Безпалова О.І. Адміністративно-правовий механізм реалізації правоохоронної функції держави : монографія. Харків : НікаНова, 2014. 544 с.

2. Безпалова О.І. Діяльність органів місцевого самоврядування щодо реалізації правоохоронної функції держави та шляхи ії удосконалення. Науковий вісник Ужгородського національного університету. Серія «Право». 2013. Вип. 23, ч. 1, т. 2. С. 96-100.

3. Кірмач А.В. Правове регулювання проходження державної служби: європейський досвід та його впровадження в Україні : дис. ... канд. юрид. наук : 12.00.07. Київ, 2010. 214 с.

4. Кравченко В.В., Пітцик М.В. Муніципальне право України : навч. посіб. Київ : Атіка, 2003. $672 \mathrm{c.}$

5. Янюк Н.В. Законодавство про службу в органах місцевого самоврядування: пропозиції з удосконалення. Часопис Київського університету права. 2015. № 4. С. 99.

УДК 342.951: $346.21 / 346.9$

DOI https://doi.org/10.32844/2618-1258.2019.6.29

ЗАМРИГА А.В.

\section{АДМІНІСТРАТИВНА ПРОЦЕДУРА КОНТРОЛЬНО-НАГЛЯДОВОГО ПРОВАДЖЕННЯ У СФЕРІ АДМІНІСТРАТИВНО-ПРАВОВОГО ЗАБЕЗПЕЧЕННЯ ГОСПОДАРСЬКОЇ ДІЯЛЬНОСТІ В УКРАЇНІ}

У статті розкрито контрольні та наглядові дії публічної адміністрації у сфері адміністративно-правового забезпечення господарської діяльності в Україні з нового погляду та в аспекті необхідних змін до запровадження, які якнайближче підштовхнуть країну до утвердження себе як сервісної, такої, що в першу чергу дбає про своїх громадян та сприяє розвитку їхніх бізнесових починань. Наголошено, що оскарження судового рішення про виявлення (відсутність) ознак правопорушення в діях суб'єкта господарювання стосується саме контрольно-наглядової діяльності публічної адміністрації. На ній акцентується увага, тому що це специфічний різновид діяльності публічної адміністрації, який поєднує сервісну та адміністративну діяльність і слугує чинником не притягнення до відповідальності суб' єкта господарювання, а допомоги йому 3 метою зорієнтувати, і тільки у випадку нехтування допомогою - притягнути до відповідальності. Визначено, що ризик-орієнтований контроль залишиться для представників великого бізнесу, так званих «олігархічних монополістів», а середній та малий бізнес матимуть можливості для реалізації своєї господарської діяльності без надмірних адміністративних бар'єрів. Однак це не означає, що їхня діяльність буде безконтрольною. Запровадження контрольно-наглядових дій надасть можливість громаді самостійно моніторити провадження господарської діяльності конкретного суб'єкта. Зроблено висновок, що адміністративна процедура контрольно-наглядового провадження у сфері адміністративно-правового забезпечення господарської діяльності в Україні має передбачати партнерські стосунки влади і бізнесу, а не виключно владну діяльність. Для того щоб адміністративна сервісність дійсно стала провідною ознакою діяльності української держави, необхідно здійснити ряд суттєвих реформацій. Для виправлення такого стану речей для початку необхідно здійснити перегляд наявних поглядів на ефективне функціонування основних інститутів, які напряму мають взаємодіяти з бізнесом. У такому аспекті актуальним убачається внесення докорінних змін і окремих доповнень до Закону України «Про основні засади державного

ЗАМРИГА А.В. - кандидат економічних наук, докторант (Науково-дослідний інститут публічного права) 